\title{
模型実験によるキャンバス式とオッタ一式の 中層トロール網の力学的特性の比較*1
}

\author{
胡 夫祥, 松田 晈, 小池 篤
}

(1988 年 12 月 7 日受付)

\section{Comparison of Mechanical Characteristics Between Canvas Type and Otter Type Midwater Trawl Net in a Flume Experiment}

\author{
Hu Fuxiang, ${ }^{* 2}$ Ko Matsuda,*2 and Atsushi Koike*ะ
}

\begin{abstract}
In order to clarify the performance of the midwater trawl net using a new net-mouth opening device made of canvas, their static and dynamic characteristics were compared to those of the otter type in a flume experiment. It was observed that the canvas type midwater trawl net was suited to low-speed towing because its relative mouth opening area to the total drag of gear was high at low-speed. On the other hand the otter type midwater trawl was suited to high-speed towing. Comparing both types of midwater trawl in the control performance of working depth by changing the current speed, the time required to control the working depth by the same floating or sinking distance for the canvas type was shorter than that for the otter type.
\end{abstract}

前報》で著者らは，オッターボードの代わりに両袖網 の外䚋にキャンハス製拡絧装固を取付けた中層トロール 䋧を設計し、模型実験によりそのンステムの静的特性を 明かにた。しかし，新たに開発した中層トロールシス テムは，従来のオッターボードを用いたるのとは方式を 全〈異にするため，このシステムを実用化するには，両 方式の特箇を比較する必要がある。

ここでは，同一の模型網を用いて，キャン六製抬絧 装置を用いた場合（キャンバス式）とオッターボードを 用いた場合（オッタ一式）に拈ける静的特性並びに動的 特性について，両方式の比較を試みた。

\section{方法}

模型刺 前報1)で模型案験の 原型とした全長 $19.5 \mathrm{~m}$ の中層トロール純を実物絹として，その 25 分の 1 の模 型綟老 Tauti ${ }^{2\rangle}$ の比較則に基いて作成した。模型網の全 長は $0.78 \mathrm{~m} て ゙$, 網地はすべてナイロン $210 \mathrm{~d} / 2$ 本, 目 合 $16 \mathrm{~mm}$ を用いた。ネットペンダントは前報》と同様 3本にし，長さを $0.36 \mathrm{~m}$ とした。両タイプに使用したワ ープの長さは $2.4 \mathrm{~m}$ である。またキャンバス式はネット ベンダントとワーブの連結部に䊖を沈下させるため 22 gwのフロントウェイトを取付けた。静的特性を比較す るためのオッター式のハントロープの長さは $2.0 \mathrm{~m} と \mathrm{~L}$
た。

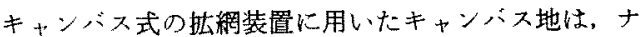
イロン帆布（厚さ $0.16 \mathrm{~mm}$ )で，大きさは，前報1) の結 果より，模型样のサイズに適した值として面積 $36 \mathrm{~cm}^{2}$ (縦横比 2.0)とした。キ+ンバスの袖絸への取付け方法 などは前報 $の$ Fig. 2 と同様にした。

オッタ一式の将ードは，綎横比 2.0 の Süberkrüb 型

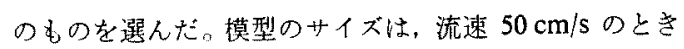
網口面積が最大心なる上うに決定された。その計算方法 は Fig. 3(a) を参考に, 網口幅 $\mathrm{B}=0.24 \mathrm{~m}$ (仕立て上が りの綝口直径) とすると，幾何学的関係より，ワープお よびハンドロープの流れとのなす角はそれぞれ $\theta_{1}=$

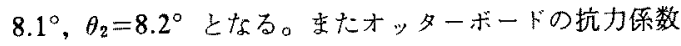
$C_{\mathrm{D}}$ と揚力係数 $C_{\mathrm{L}}$ 文文献 ${ }^{3)}$ 上り $C_{\mathrm{D}}=0.25, C_{\mathrm{L}}=1.5$ と した。当らに袋栦の抵抗を前報 ${ }^{\prime}$ より $R_{\mathrm{n}}=222 \mathrm{gw}$ と推 定すると

$$
L=\frac{R_{\mathrm{n}}\left(\tan \theta_{1}+\tan \theta_{2}\right)}{2\left(1-C_{\mathrm{D}} / C_{\mathrm{L}} \times \tan \theta_{1}\right)}
$$

上り必要な揚力は $L=34 \mathrm{gw}$ となる。したがって計算に よるオッターボートの面樻はは梳 $17 \mathrm{~cm}^{2}$ となった。し かし、オッターボードの水中重量をキャンバス式のフロ ントウェイトと等しくするため,オッターボードの厚友 を計算值より多少愿くしたことによる揚力係数の低下，

*1 本論文の大要は昭和 63 年度日産水産学会年会（東京）において報告した。

*2 東京水産大学 (Tokyo University of Fisheries, Konan, Minato, Tokyo 108, Japan). 
その他を考感して，模型のオッターボードの面積を $S=$ $18 \mathrm{~cm}^{2}$ (滈さ $6 \mathrm{~cm}$, 幅 $3 \mathrm{~cm}$ ) とした。

網抵抗と掼口形状の㖶測 キャンパス式とオッタ一式

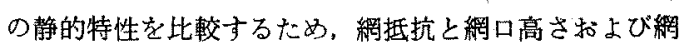
口䒇を計測した。網抵抗の計測について，小型ロードセ ル(值径 $6 \mathrm{~mm}$, 長さ $40 \mathrm{~mm}$, 水中重量 $3.5 \mathrm{gw}$ ) を用い, オッター式では，それぞれ全抵抗と袋網の抵抗を計測 し、キャンバス式では，袋網とキャンバスとが一体化し ているため，全抵抗のみを計った。また網口高さと網口 湢の計測には特別に設計された網口高さ計を用いた。こ こでは絧口高さは浮子稀と沈子綱の中心の鉛直距離を。 網口幅は两袖先のワイヤーとネットペンダントとの結び 目の水平距離を意味する。

糋梁さの㖕測 キ+ンバス式とオッター式の流れの加 速また減速による稀位直制御特性の嗱いを明らかにす る目的から，絧位置の時間的変化を計る必要がる。今 回の奉験では，小型压力七ンサー(センサー直径 $8 \mathrm{~mm}$, 長さ $6.1 \mathrm{~mm}$, 水中重量 $0.9 \mathrm{gw})$ を水深計として用いた。 これらをそれぞれ左右のネットペンダントの先端に取付 けＸYレコーダーで連続記録するシステムを採用した。 压力七ンサーの流速又は設䈯水深に関する検定結果は Fig. 1 K示す通りである。このセンサーによる計測篹差 は，流速 $80 \mathrm{~cm} / \mathrm{s}$ 亲では $5 \%$ 以内であるが，それ以上で は，多少大きくなる可能性がある。また包力計を取付け たことによる抵抗㕲よび絧梁さへの影響について子確か めたところ、いずれの流速においても，臣とんと無視で きる程度であった。

奏験は東京水産大学の回流水槽（観測部長さ $7 \mathrm{~m}$, 水 路幅 $1.45 \mathrm{~m}$, 常用水深 $1.2 \mathrm{~m}$ ) で行った。流速の計測は

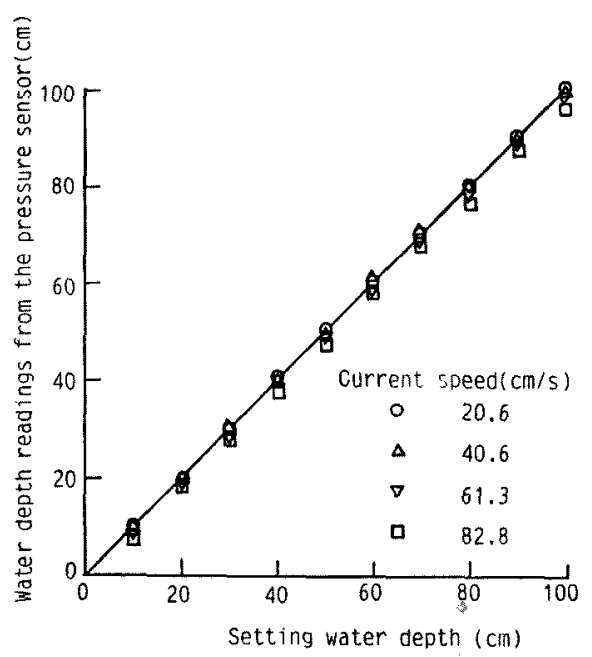

Fig. 1. Calibration line of the pressure sensor used as a depth meter.
プロペラ式小型流速計を用い，静的特性の実驗では，流 速範困は 30-100 cm/s で，李た動的特性の実験では 45$90 \mathrm{~cm} / \mathrm{s}$ の範囲で央施した。流速の加速をたは娍速の方 法は，初期流速を 45.5, 56.5, 66.5, $77.5 \mathrm{~cm} / \mathrm{s}$ の 4 段階 とし，それぞれの初期流速から加速または娍速の輻を8$11 \mathrm{~cm} / \mathrm{s}$ とした。この場合，同じ初期流速におけるキャ ンバス式とオッター式の網深さの変化量が等しくなるよ らに，流れの加速または減速幅索調節した。一方，同し 初期流速に蛙ける加速幅の違いによる䋨深さの变化も調 へた。この場合, 初期流速は $45.5 \mathrm{~cm} / \mathrm{s}$ のみとし, 加速 愊を $5-25 \mathrm{~cm} / \mathrm{s}$ とした。流れの加減速によって, 流速か 安定するまでに要する時間徒，実験範团内て，加減速幅 によらずほぼ一定であった。

\section{結果およひ考察}

網抵抗の比較 網抵抗はキャンバス式とオッター式の 両方とも流速とともに增加する。Fig. 2 はキンンスス式 とオッター式の網抵抗の流速に対する変化を示す。キャ ンバス式の全抵抗はオッター式のほほ $10 \%$ 程度上回っ ている。これは使用したキャンバスの面積がオッターボ 一ドの 2 倍であることがその主要な原因と考充られる。 つきに,オッター式に拈ける袋絧の抵抗測定值を基々， 最小自乗法で求めると，袋網の抵抗 $R_{\mathrm{n}}$ は

$$
R_{\mathrm{n}}=0.336 V^{1.44}
$$

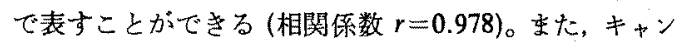

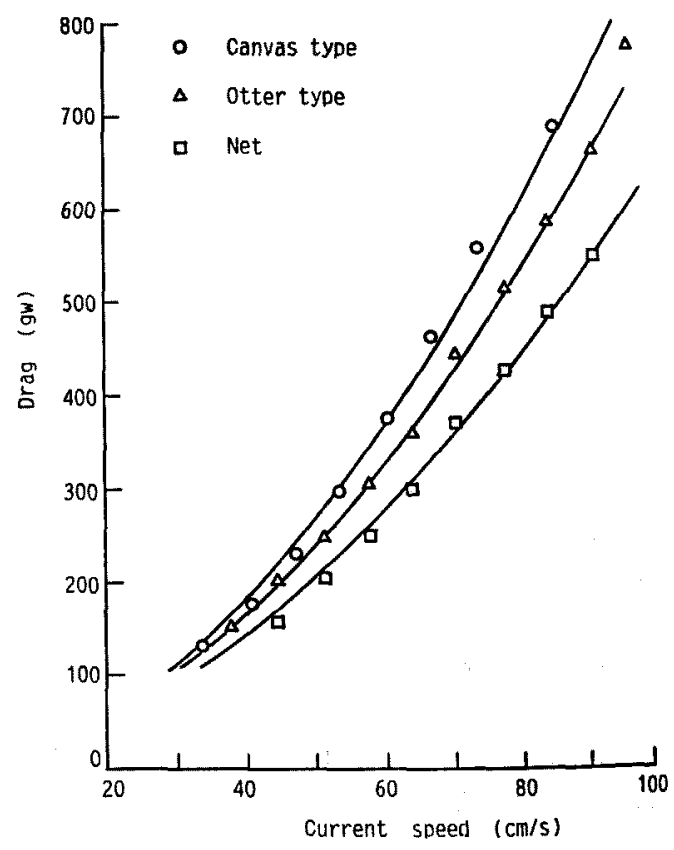

Fig. 2. Changes of drag of two types of gears and the net agains current speed. 


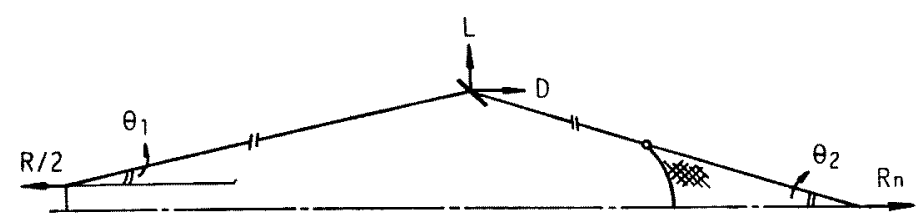

(a) Otter type

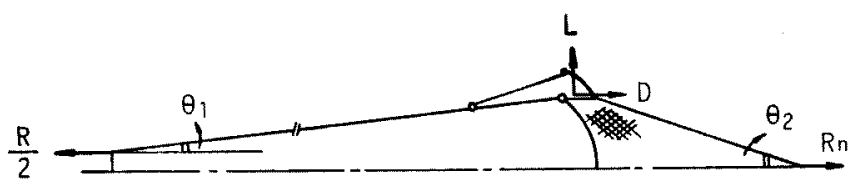

(b) Canvas type

Fig. 3. Schematic diagrams showing the equilibrium of horizontal forces acting on the otter type and the canvas type midwater trawl. $R$ and $R \mathbf{n}$ are the total drag of gear and the drag of net, $\theta_{1}$ and $\theta_{2}$ are the attack angle to current of the warp and the lacing line, $L$ and $D$ are the lift and drag of the otter board (a) or the canvas mouth opening device (b), respectively.

ハズよびオッターボードの揚力保数は模型実験で得ら んた網の抵抗測定值よりキャンバスをたはオッターボ 一ドの力学的釣合い関係から推定した。Fig. 3(a) および (b) はそれぞれオッター式とキャンバス式の平面的な力 钩合を示寸図である。ここで $R$ および $R_{\mathrm{n}}$ はそれそれ キャンハス式またはオッタ一式の全抵抗および袋網の抵 抗，L就よ゙Dはそれぞれキャンハスをたは才ッター 玄ードの揚力および抗力， $\theta_{1}$ はワーブの流れとのな寸角，

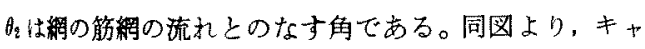
シハスをたはオッターボードの掦力は

$$
L=\frac{R}{2} \tan \theta_{1}+\frac{R_{n}}{2} \tan \theta_{2}
$$

て麦せる。ここで角 $\theta_{1}$ 括よび $\theta_{2}$ は模型奏験の条件か ら，またキャンハス式の袋網の柢抗 $\left(R_{\mathrm{n}}\right)$ は (2) 式を用 いると、キャンバスまたはオッターボートの措力保数 C 1 (3) 式を用いて

$$
C_{\mathrm{L}}=\frac{L}{(1 / 2) \rho V^{2} S}
$$

加求められる。この上らにして求めたキャンハス扰よ びオッター゙ートの揚力係数 $C_{\mathrm{L}}$ を Fig. 4 に示す。才 ルターボードの掦力係数は流速とともに 0.98 から 1.44 まて增加している。このよらに揚力係数が流速とともに 增加するのはオッターボートの迎角が流速ととすに増大 †るのではないかと推測される。

一方キャンバスの揚力保数は流速によらずほぼ一定 値を示したが，ての值は 0.43 とかなり低い値となった。 このことは今回の実験に用いたキャンハススじく笚純な 平布型のあので，流れにあたるとキャンハス製扗網装瞋

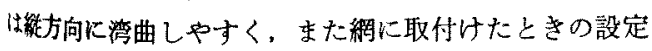

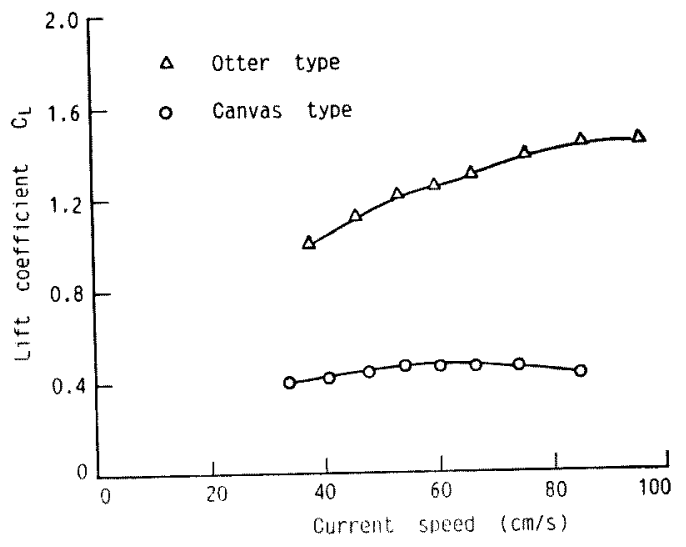

Fig. 4. Values of lift coefficient of the otter board and the canvas mouth opening device.

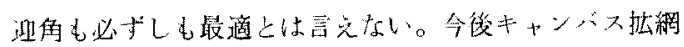

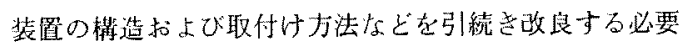
がある。

網口形状の比較 キャンパス式拈上びオッタ一式の網 口高さ括よび种口幅と流速との関係を Fig. 5 に亦寸。 網口高さは, 耐タイプとも流速の増加とともに急激に低 下するが、キャンバス式の網口高さはオッター式のとれ 上り全体的に低い值を示している。一方, 網口幅恃。 キ サシハ大式では、流速 $70 \mathrm{~cm} / \mathrm{s}$ 付近李では急激に增大寸 るが，てれ以上では変化が少ない。これに対して，オッ タ一式では, 流速 $90 \mathrm{~cm} / \mathrm{s}$ 付近末では流速とともに急激 に增大した。同図よりキャンス大式の絧口幅はオッタ

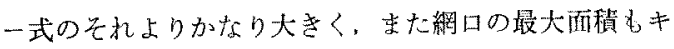
ナンハス式の方はオッタ一式を上回っているが，能口面 


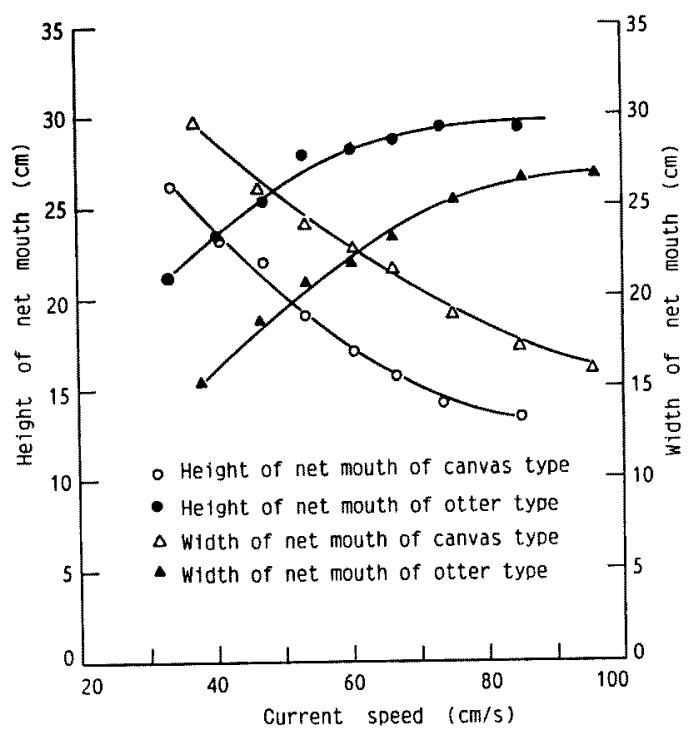

Fig. 5. Comparison of the net height and the wing-end width of two types of gears.

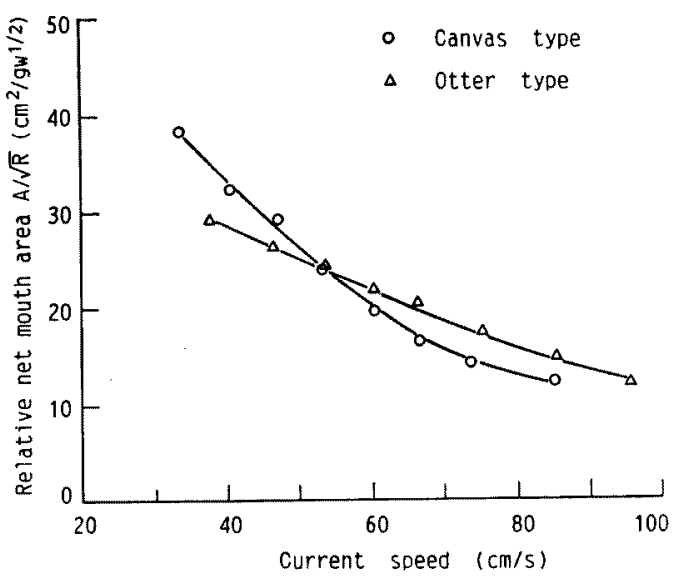

Fig. 6. Comparison of the relative values of the net mouth area to the square root of gear drag of two types of gears.

積が最大になる流速はキャンバス式の方が低い。

つぎに，再方式の相対性能を比較する目的から，前

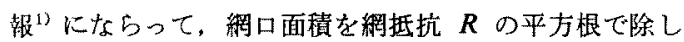
た值を相対絧口面積と定義した。キャンバス式およびオ ッター式の相対網口面積と流速の関係を Fig. 6 K示す。 相詨縄口面積は耐タイブとも流速とともに減少するが， 曲線の勾配はキャンバス式の方が急である。この結果か ら，前報”でも述べたよらに，オッター式に比べ，キャ

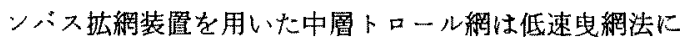
適することを示唆している。

㮶位置制御特性の比較 中殿トロールシステムでは，

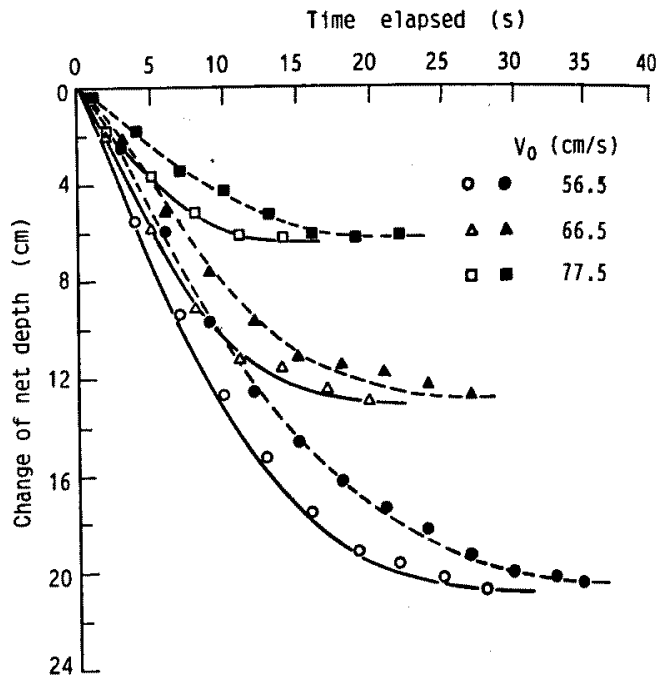

Fig. 7. Changes of net depth in floating process by the acceleration of current speed. $V_{0}$ is the initial speed of current. The real and broken lines indicate the canvas type and the otter type, respectively.

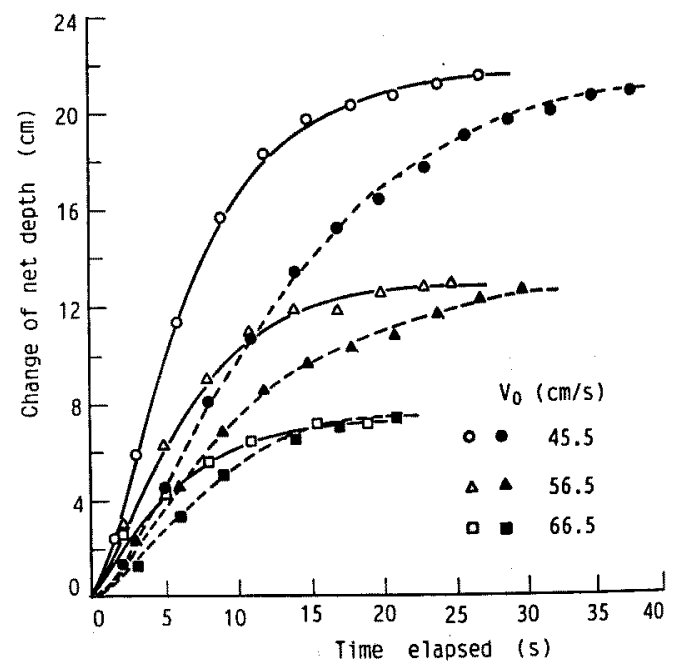

Fig. 8. Changes of net depth in sinking process by the reduction of current speed. The real and broken lines indicate the canvas type and the otter type, respectively.

絧位置制御特性は漁獲に密接な関係をるつ重要な特性で

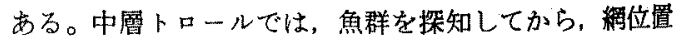
を効果的に魚群の遊泳水㳭に制御する必要がある。

網深さを制御するには，曳網速度を变化させる方法 と、ワープの長さを変える方法がある。ここでは，実的 装置の関係で, 前者の方法により, 回流水槽の流速を変 化させる方法によって，網位置を制御した。Fig. 7 は， 
Table 1. Comparison of control character istics of net depth of canvas type and otter type midwater trawl due to changes of current speed

\begin{tabular}{|c|c|c|c|c|c|c|c|c|}
\hline & \multirow{2}{*}{$\begin{array}{l}\text { Length } \\
\text { of hand } \\
\text { rope } \\
\text { (m) }\end{array}$} & \multirow{2}{*}{$\begin{array}{c}\text { Initial } \\
\text { current } \\
\text { speed } \\
V_{0}(\mathrm{~cm} / \mathrm{s})\end{array}$} & \multicolumn{3}{|c|}{ Acceleration experiment } & \multicolumn{3}{|c|}{ Reduction experiment } \\
\hline & & & $\begin{array}{c}\text { Increment } \\
\text { of speed } \\
\Delta V(\mathrm{~cm} / \mathrm{s})\end{array}$ & $\begin{array}{c}\text { Change of } \\
\text { net depth } \\
\Delta Z(\mathrm{~cm})\end{array}$ & $\begin{array}{c}\text { Elapsed } \\
\text { time } \\
T_{\infty}(\mathrm{s})\end{array}$ & $\begin{array}{l}\text { Decrement } \\
\text { of speed } \\
\Delta V(\mathrm{~cm} / \mathrm{s})\end{array}$ & $\begin{array}{l}\text { Change of } \\
\text { net depth } \\
\Delta Z(\mathrm{~cm})\end{array}$ & $\begin{array}{c}\text { Elapsed } \\
\text { time } \\
T_{\infty}(\mathrm{s})\end{array}$ \\
\hline \multirow{4}{*}{ Canvas type } & & 45.5 & 11.0 & 20.7 & 29.7 & & & \\
\hline & & 56.5 & 10.5 & 13.1 & 27.5 & 11.0 & 21.0 & 38.7 \\
\hline & & 66.5 & 11.0 & 7.6 & 23.4 & 11.0 & 13.8 & 31.0 \\
\hline & & 77.5 & 10.0 & 5.0 & 15.8 & 10.5 & 6.4 & 21.4 \\
\hline \multirow{11}{*}{ Otter type } & \multirow{3}{*}{1.5} & 45.5 & 10.0 & 22.6 & 39.1 & & & \\
\hline & & 56.5 & 9.8 & 13.6 & 36.2 & & & \\
\hline & & 66.5 & 10.0 & 7.3 & 26.3 & & & \\
\hline & \multirow{4}{*}{2.0} & 45.5 & 7.3 & 22.0 & 57.0 & & & \\
\hline & & 56.5 & 7.5 & 13.8 & 49.7 & 7.5 & 21.3 & 52.1 \\
\hline & & 66.5 & 7.2 & 7. & 33.6 & 7.0 & 12.4 & 40.2 \\
\hline & & 77.5 & 7.8 & 4.7 & 21.9 & 7.0 & 6.5 & 31.6 \\
\hline & \multirow{4}{*}{2.5} & 45.5 & 6.8 & 22.0 & 61.0 & & & \\
\hline & & 56.5 & 6.6 & 14.3 & 55.2 & 7.0 & 20.0 & 51.4 \\
\hline & & 66.5 & 7.0 & 7.7 & 42.7 & 6.0 & 15.0 & 48.4 \\
\hline & & 77.5 & 7.0 & 4.9 & 28.8 & 5.5 & 6.1 & 35.5 \\
\hline
\end{tabular}

定常状態から流速を一定值だけ加速した場合 (加速実験) で初期流速 $V_{0}$ をパラメータとしたときの網の浮上距 路 $\Delta Z$ の時間的变化を示す。実線はキャンバス式, 破線 はオッタ一式である。同因上り明らかに、いずれの初期

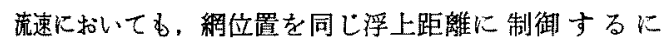
は，キャンハスス式の方がオッタ一式より網位置の安定す るまで要する時間は短いことがわかる。Fig. 8 は，定 常状態から流速を一定值だけ減速した場合 (减速実験) を示寸。Fig. 7 と同様に，同し距離だけ沈下させるため に要する時間はキャンバス式はオッター式より短い。 キャンバス式とオッタ一式の網位置制御に打けるこのよ らな時間差か生したのは, 主としてオッター式中層卜口 一ル網のハンドロープの長さに起因すると考元，オッタ 一式のハンドロープの長さを $1.5 \mathrm{~m}, 2.0 \mathrm{~m}, 2.5 \mathrm{~m}$ の 3 段階に変化させて実験した。その結果を Table 1 亿京と めた。 $\Delta Z$ は網深さの変化量で, 加速実駼の場合では $\Delta Z=Z_{0}-Z_{\infty}$, 減速の場合では $\Delta Z=Z_{\infty}-Z_{0}$ 。しした。 $Z_{0}$ 性流九を変化させる前の絧深さで， $Z_{\infty}$ は流れを变化さ 世九後の網位置の平衡深度で，定差図法より求めた值で ある。また網か平衡深度 $Z_{\infty}$ の $99 \%$ まで浮上または沈 下するに要する時間制御洔間 $T_{\infty}$ とした。制御時間 $T_{\infty}$ は，加速または減速のいずれの場合でも，キャンバス式 からオッター式のハンドロープの長い順に増加する。そ れ虫ハンドロープを介入したオッター式中層トロール網 で網位置の制御が間接になり，ハンドロープが長いは と制御特性が悪くなることを示唆している。Table 1 よ ク、同じタイプ場合，いずれの初期流速でる，加減速

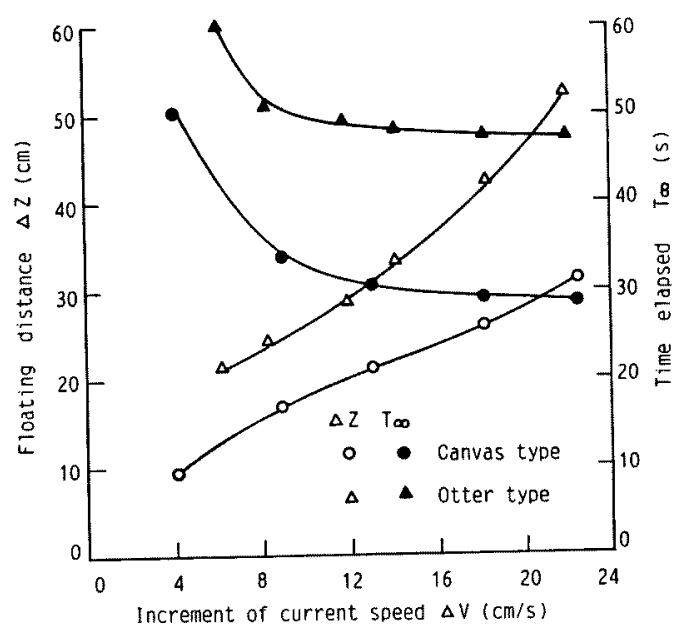

Fig. 9. Variations of the floating distance of net and the time elapsed against the increment of current speed.

幅は活ぼ同しににしたので，初期流速が增すと網位置の変 化量が小さくなり， $T_{\infty}$ 名隇少する傾向にあり、初期流速 が大きい压ど，減衰も大きいことを示している。

次に，キャンジス式とオッター式の初期流速 $V_{0}=45.5$ $\mathrm{cm} / \mathrm{s}$ K猢る加速幅 $\Delta V$ に対する網の浮上距離 $\Delta Z$ と 制御時間 $T_{\infty}$ の関係を Fig. 9 に示す。浮上距離は両夕 イプとも加速幅とともに增大する。その増大傾向はキャ ンパス式は直線的であるが、ホッター式は加速幅ととる に浮上量が增大する傾向を示した。しかし，制御時間 $T_{\infty}$ 
は，全体的にはキャンハス式はオッター式に比へてて短い が，加速幅が小さいときはいずれの場合も加速幅の增加 とともに急激に減少し, 加速幅か一定値を超寸と減少の 割合は極めて小さくなる。

\section{要約}

同一の模型網妾用いたキャンバス式とオッター式の中 穓卜ロー儿絧の静的, 動的特性を水槽実験で調べて比較 した。それらの結果を要的すると次の通りである。

(1) 網抵抗は，キャンバス式とオッタ一式の両方と

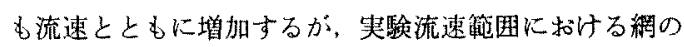
全抵抗はキャンバス式の方がオッター式をほほ $10 \%$ 程 度上回っている。網抵抗の测定値から推定されたキャン バスの掦力係数はオッターボードのをれよりかなり低い 値を示した。

（2）䋧口高さはキキャンハス式の方がォッタ一式よ り全体的に低い值を示したが，キャンパス式の網口幅は オッター式のそれよりかなり大きく、キャンバスの抬網
効果は十分認められた。また相詨網口面積は低速はどオ ッター式よりキャンバス式の方が大い值を示した。

（3）回流水槽の流速を加減速させて，両方式の絧梁 ざ制御特性を比較した。いずれの初期流速に竹いても， 網位置を同じ浮上（沈下）距離に制御するには、キャン バス式の方がオッター式より網位置の安定するまで炕要 する時間がかなり短いことは明らかになった。また同一 方式の場合，同じ初期流速に括いては，加速幅の增大に 従って網位直の浮上距離が少なくなり，網位着の安定す るまでに要する時間も短かくなることがわかった。

\section{文萳}

1) 松田 佼, 胡夫祥, 小池 篤：日水誌， 54, 1783-1788 (1988).

2) M. Tauti: Nippon Suisan Gakkaishi, 3, 171177 (1934).

3) FAO: Otter board design and performance, FAO, Rome, 1964, pp. 1-79. 